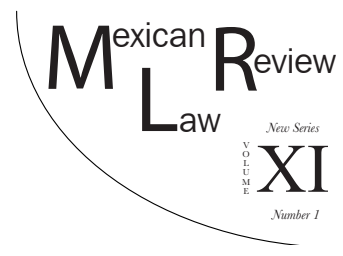

\title{
UNPACKING THE MEXICAN FEDERAL JUDICIARY: AN INNER LOOK AT THE ETHOS OF THE JUDICIAL BRANCH
}

\author{
Gabriel FERREYRA*
}

\begin{abstract}
Based on 45 interviewes conducted in 6 different jurisdictions in Mexico, this article presents a close examination of the distinctive attributes and practices that characterize the Mexican Federal Fudiciary (Poder Fudicial Federal). Interviewees included typists, clerks and court clerks, judges, and justices, as well as scholars and experts with an in-depth knowledge of this institution. From an insider perspective, the article sheds light on idiosyncrasies, customs, and organizational patterns that are not well known outside the MFF, such as its strong hierarchical structure, the nature of the work done, employee salaries, the practices of legalism, the risks of drug-related trials, and structural gender inequalities. It also discusses phenomena like influence peddling, cronyism, and nepotism, all of which are widely practiced within the MFF but kept undisclosed. These practices do not necessarily have a negative connotation within the federal judiciary because they have become normalized due to their widespread use. In fact, the notion of corruption is somehow ambiguous for many judicial employees. Despite all this, the MFF has become a more professionalized branch where the vast majority of employees performed their job competently and efficiently.
\end{abstract}

Key Words: Mexican Federal Fudiciary, Misconduct, Legal Studies, Qualitative Methods, Ethnography.

RESUMEN: El presente artículo aborda un análisis exhaustivo la cultura y costumbres que prevalecen en el Poder Fudicial Federal en México. Este trabajo está basado en una investigación de campo que se realizó en 6 diferentes

* Law and philosophy degrees from Universidad Michoacana de San Nicolás de Hidalgo, Michoacán, Mexico. The author has litigated criminal, family and property law in Mexican courts for several years. M.A. in Cultural Anthropology at the University of Texas at San Antonio. PhD in Justice Studies at Arizona State University. He is currently Assistant Professor of Criminal Justice at Texas A\&M University - Corpus Christi. The author wants to thank two helpful anonymous reviewers for their comments and feedback. Email: gabriel.ferreyra@tamucg. edu. 
Esta revista forma parte del acervo de la Biblioteca Jurídica Virtual del Instituto de Investigaciones Jurídicas de la UNAM

ciudades del país donde se entrevistaron a 45 personas, entre ellas oficiales administrativos, actuarios, secretarios de juzgados, proyectistas, jueces de distrito, magistrados de colegiados, personal del Consejo de la Fudicatura, expertos y litigantes. El análisis de esta propuesta conlleva una perspectiva desde adentro respecto de algunas prácticas comunes al interior del Poder Fudicial Federal como son la existencia de una estructura jerárquica poderosa, el tipo de trabajo de todos los días, los salarios, el legalismo exacerbado, los riegos de resolver juicios relacionados con el narcotráfico y cuestiones de inequidad institucional. También se discuten temas como el tráfico de influencias, el amiguismo y el nepotismo los cuales están ampliamente arraigados en la institución. De hecho, el tema de la corrupción tiene una connotación ambigua entre empleados del PFF porque no hay politicas institucionales para resolverlo ya que oficialmente este problema no existe. A pesar de lo anterior, el PJF se ha profesionalizado y la mayoría de empleados realizan sus labores de una manera eficaz y competente.

Palabras clave: Poder Fudicial Federal, Conductas Ilegales, Estudios de Derecho, Métodos Cuantitativos, Etnografia.

\section{Table of Contents}

I. INTRODUCTION

1. An Overview of the Judicial Branch......................................... 59

2. Methodology

3. Federal vs. State Judicial System

4. Structure and Organization of the Federal Judiciary

II. Understanding the Setting

1. Hierarchical Structure

2. Too Much Work!

3. High Salaries and Vocation 66

4. Justices, Magistrates, and Council Member Salaries

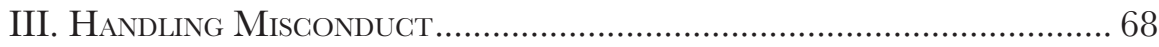

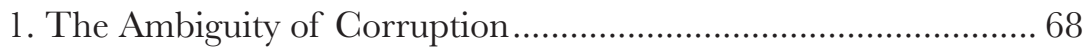

2. Traffic of Influence and the Use of Connections........................ 70

3. Caveats on the Use of Connections............................................ 70

4. The Normalization of Nepotism ............................................... 72

5. Handling Drug-Related Trials: Are Cartels at Threat

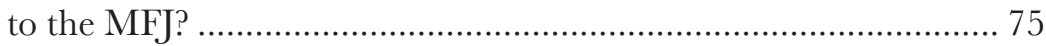

6. When the Rule of Law Leads to Impunity ................................. 77

IV. Gulture, Inequality, and Discrimination .................................. 79

1. Structural and Institutional Inequalities at the MFJ ................... 79

2. Traditional Gender Roles and Stereotypes................................. 80

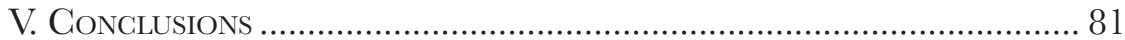


Esta revista forma parte del acervo de la Biblioteca Jurídica Virtual del Instituto de Investigaciones Jurídicas de la UNAM

\section{INTRODUCTION}

\section{An Overview of the Fudicial Branch}

In late February 2011, a documentary called Presunto Culpable (Presumed Guilty) was released in Mexican theaters. The documentary tells the story of Antonio Zuñiga (a.k.a. Toño), a 26-year-old street vendor in Mexico City who was sentenced to 20 years in prison for a murder he did not commit. Toño contacted two young Mexican lawyers to help review his case. After a thorough study of the case, these lawyers found legal inconsistencies in the trial that led to an official reopening of the case and a new trial. The film captures the proceedings of the new trial and the interactions between the defendant, the witnesses, the judge, and the Mexican criminal justice system. The documentary presents the shortcomings of crowded prisons in Mexico City and the fight to prove the defendant's innocence. ${ }^{1}$

Watching Presumed Guilty confirmed many viewers' pre-existing view of the Mexican judicial system as an unfair, bureaucratic, discriminatory, and Kafkaesque institution. Although Mexican people are aware of the prevalence of corruption in societal and governmental settings, as well as how corruption is used as a tool to navigate the political and social systems, the content of the documentary was still shocking in several ways. First, the storyline was compelling because of the context and circumstances of the main character. Second, it was a true story that resonated in the minds of Mexicans due to the familiar circumstances of the case; that is, people believed it because such stories are not uncommon in Mexico. Third, Mexican society was suspicious because at some point a judge wanted to prohibit the film from being shown and this was seen as a cover-up.

Beyond the police, no other institution in Mexico generates as much dissatisfaction and lack of trust as the criminal justice system and its main components: the police, the office of the public prosecutor, and the / court system. When dealing with any of these agencies, most Mexicans assume that corruption, and the judicial branch in particular, hold the blame for the widespread impunity in the country. For different reasons, many Mexicans are unaware of the fact that the criminal justice system is not a monolithic institution but a complex organization composed of an array of governmental agencies belonging to different branches. A common misunderstanding is to assume that the public prosecutor's office belongs to, or is part of, the judicial system. This confusion has led many people to think that when a criminal walks out of prison unpunished during or after a trial it is because the judicial system is corrupt or inefficient. This is not always the case; many times legal techni-

\footnotetext{
1 Roberto Hernández \& Geoffrey Smith. Presunto culpable. DVD. Mexico City. Instituto Mexicano de la Cinematografía, (2008).
} 
calities ignored by the prosecutor before the indictment create loopholes that force judges to release someone who might be responsible for a crime.

When Mexican people are asked what they think about the judicial system, most of them confuse state and federal judiciaries in addition to having a negative opinion of both. This attitude is illustrated in a 2008 survey from the Citizen Institute for Studies on Public Safety, which showed that only $8 \%$ percent of the population has high confidence in the judicial system. ${ }^{2}$ This means that the vast majority of Mexicans distrust the judicial system as a whole, whether is at a local or federal level.

\section{Methodology}

Given the common misunderstanding of the federal judicial system, this article exclusively describes and problematizes the different idiosyncrasies, customs, and organizational patterns that have become part of the everyday life in the federal judicial branch and are not very well known outside its boundaries. The main focus of this article is to shed light on the inner workings of the federal judiciary in order to understand how this institution conducts its everyday business while dispensing justice. Although the primary focus is the federal judiciary, the patterns, legal culture, and problems described here may apply to some (but not all) state judicial systems in Mexico given the similarities and homogeneity of the Mexican judiciary. Although there is some mention of other criminal justice system institutions, such as the Office of the Public Prosecutor, this article centers on the Mexican Federal Judiciary-MFJ- (Poder Fudicial de la Federación).

This research project uses a qualitative research approach mostly based on semi-structured interviews and archival documents. The interviews took place during fieldwork in 6 Mexican cities (Acapulco, Mexico City, Morelia, Nogales, Puebla, and Tijuana) in the summer of 2011. There were a total of 45 interviewees: 16 women and 29 men. Out of those, 40 were employees working for the MFJ, 2 were expert attorneys who litigated in federal courts, and 3 were Mexican scholars with expertise in this institution. Among the 40 interviewees working for the MFJ, I interviewed 3 justices, 7 federal district judges, 14 district court law clerks, 4 appeals court law clerks, 5 typists, 2 process servers, 4 federal public defenders, and 1 council clerk. The rationale for this selection was to have a representative sample from all the areas of the MFJ and the number of people interviewed was enough to provide a rich and holistic description of the setting after having reached what is known as

\footnotetext{
2 Instituto Giudadano de Estudios sobre la Inseguridad A.C. Quinta encuesta NACIONAL SOBRE INSEGURIDAD, (2008). Available at http://wreweicesi.org.mx/documentos/propuestas/ cuadernos_icesi.pdf.
} 
the saturation point: where there was no new data coming in from the last interviewees and the same topics were repeated. ${ }^{3}$

To select interviewees I employed a mixed methodology of snowball and convenience sampling. Since I studied law in Mexico and litigated there for several years, I had an extensive network of peers, former classmates, and acquaintances working in the federal courts. I approached them and asked if they would agree to an interview about the MFJ. Most of them agreed as long as the information remained confidential. Through them I was able to contact other potential participants who also agreed to be interviewed. Thus, the snowball sample came from this strategy. In jurisdictions where I did not know anyone, I introduced myself to court officials and requested an interview. This approach was harder to do and took longer than the previous one since several potential interviewees turned down my request. However, I persisted. Although I spent more time convincing officials and rescheduling interview appointments, I ended up having a representative pool of court employees. Thus, the convenience sampling resulted from this planning. All in all, two thirds of the sample was interviewed using a snowball approach and one third using convenience sampling. The archival research was conducted mostly on official information made available by the Mexican Federal Judiciary either through its well-organized and informative website or through books, brochures, fact sheets, and press releases.

One innovative contribution of this article is that it gives a voice to Mexican public officials working in the judicial branch so they can express themselves about everyday life and practices in their work environment without censure. Since confidentiality for all interviewees was guaranteed, they were able to explain in detail the culture, unwritten rules, and patterns that would otherwise have been difficult to capture. Therefore, pseudonymous are used throughout the entire article. One primary goal of this article is to offer an internal perspective of the inner life of the MFJ provided by people who have worked, studied, or litigated in the Mexican Federal Judiciary.

\section{Federal vs. State Fudicial System}

Similar to the U.S. federal system, Mexico's political authority is composed of a central government located in Mexico City (formerly known as Federal District) and 31 self-governing political divisions called states. Each state has its own constitution, governor, legislature, and judicial system. The state judicial systems are organized into a two-tier hierarchical structure of lower courts (juzgados) and appeals courts (salas). The former are headed by state judges (jueces del fuero común) and the latter by state justices (magistrados del fuero común). There is also a state supreme court that is the highest authority of

3 Emily s. Adler \& Roger Glark, An Invitation to Social Research: How It's Done, (Wadsworth, 2011). 
Esta revista forma parte del acervo de la Biblioteca Jurídica Virtual del Instituto de Investigaciones Jurídicas de la UNAM

each state judiciary, and most states now have a State Judicial Council (Consejo de la Fudicatura Estatal) in charge of managing the budget, career civil service, and administrative affairs.

The Mexican federal judiciary on the other hand is one of the branches of the central government, the judicial branch, which is part of the governing model based on the division of powers. The Supreme Court of Justice is the highest authority of this institution. Lower and appeals courts distributed throughout the country are in charge of federal matters, such as drug related crimes, people trafficking, and arms trafficking. Compared to state judiciaries, the federal judicial system enjoys a better social status and recognition from the legal community, attorneys-at-law, and citizens who gone to court and know both the federal and state judiciaries.

The prestige of the Mexican federal judiciary comes from two sources. First, as a federal authority its budget is considerably larger than that of any of the state judiciaries, which allows it to have more human and material resources and to provide higher quality service to the community. Second, the federal judiciary has jurisdiction over the constitutional guarantee for a form of civil rights protection called an Amparo. An amparo is "a constitutional provision peculiar to Mexico which resembles United States writs of prohibition, certiorari, injunction, and habeas corpus." Amparo means "protection, aid, or shelter" in Spanish. Although the Amparo was an original Mexican creation, it combines national and international influences from legal principles like the habeas corpus, injunction, certiorari, and error of mandamus. ${ }^{5}$

\section{Structure and Organization of the Federal Judiciary}

The organization and makeup of the Mexican federal judiciary is defined by the Mexican constitution (Constitución Politica de los Estados Unidos Mexicanos). Article 94 states that the "judicial power of the Federation [Poder Fudicial Federal] is vested in a Supreme Court of Justice, in an electoral court, circuit courts, unitary courts and district courts." ${ }^{\prime 6}$ This article stipulates that the discipline, monitoring, and organization of the judicial branch (except the Supreme Court) will be in the hands of the Federal Judicial Council (Consejo de la Fudicatura Federal), which operates according to the guidelines established in the constitution and the applicable laws.

4 Louis A. Robb. Dictionary of Legal Terms Spanish-English and English-Spanish 74 (Limusa, 1979).

5 Sara Schatz et al., The Mexican Judicial System: continuity and change in a period of democratic consolidation, in Reforming the Administration of Justice in Mexico 197,223 (W.A. Cornelius \& D. Shirk eds., 2007).

6 Constitución Política de los Estados Unidos Mexicanos [Const.] as amended in 1994, Article 94, Diario Oficial de la Federación [D. O.] 5 de febrero de 1917 (Mex.). 
Esta revista forma parte del acervo de la Biblioteca Jurídica Virtual del Instituto de Investigaciones Jurídicas de la UNAM

The Federal Judicial Authority Organization $\mathrm{Act}^{7}$ governs the internal affairs of the federal judiciary. This law regulates the work and the responsibilities of those who work in the judicial branch, and outlines the jurisdiction of the federal courts. There are other secondary laws, such as the New Amparo Act (Nueva Ley de Amparo), the Federal Civil Procedure Code (Código Federal de Procedimientos Civiles), and the Federal Criminal Code (Código Penal Federal) that regulate specific legal procedures and activities for legal proceedings.

The main components of the Mexican Federal Judiciary are: 1. The Supreme Court (Suprema Corte de Fusticia de la Nación) composed of eleven justices (called Ministros) who function either as a full court (Pleno) or in two chambers. This is the highest court of the country. 2. Electoral Court (Tribunal Electoral del Poder Judicial Federal) is a specialized organ of the federal judiciary and the highest court for electoral disputes. It is composed of a full court (Sala Superior) and five regional chambers (Salas Regionales). 3. Federal Appeals Courts (Tribunales Colegiados de Circuito) are courts composed of three justices that are located throughout the country in 32 jurisdictions known as Circuitos fudiciales Federales, one for each state and one for Mexico City. They have jurisdiction over direct Amparo suits against definitive rulings, appeals (Recursos de Revision) against sentences (related to any legal matter except criminal trails) issued by district judges, administrative complaints (Quejas), and the like. 4. Criminal Appeals Courts (Tribunales Unitarios de Circuito) composed of a single justice . They are located in each state and in Mexico City (32 jurisdictions). 5. Federal District Courts (fuzgados de Distrito) are the lower courts and the MFJ's workhorse since they handle most of the proceedings and trial-related hearings. 6. The Federal Judicial Council (Consejo de la fudicatura Federal) is a recently-created institution in the Mexican Federal Judiciary. It was the result of a major overhaul of the judicial branch in 1994-1995. The Council is made up of seven members known as council members (Consejeros).

There are other important institutions in the MFJ that are subordinated to the Judicial Council, but enjoy some autonomy. One is the Institute of the Federal Judiciary (Instituto de la fudicatura), an organization specializing in training and providing legal education to members of the federal judiciary through classes, courses, and workshops. The other is the Federal Institute of Public Defense (Instituto Federal de Defensoria Pública), an organization with a good reputation among the judicial community for high quality and good service. This agency provides legal counselling for people dealing with the federal judiciary and who cannot afford to pay a private attorney. The aforementioned courts and institutions are the most important parts of the Mexican Federal Judiciary. The Supreme Court stands out as the most powerful and visible organ of the judicial branch in Mexico. Indeed, many people and some journalists appear to believe the Supreme Court is the entire federal

${ }^{7}$ Ley Orgánica del Poder Judicial de la Federación [L.O.P.J.F.] [Federal Judicial Branch Law], (Mex.). 
Esta revista forma parte del acervo de la Biblioteca Jurídica Virtual del Instituto de Investigaciones Jurídicas de la UNAM

judiciary. After analyzing the data collected from all the interviews, the following are the most important findings of the research project that reflect the culture, characteristics, and stratified organizational style of the Mexican Federal Judiciary.

\section{Understanding the SetTing}

\section{Hierarchical Structure}

One of the most visible features of the federal judiciary is its organizational structure. Similar to other government organizations in Mexico, the judiciary has built strong hierarchies with categorical levels of administration and power. Subordination to a higher authority - such as a judge, an appeals court, or the Supreme Court - is the principle that glues together the different units of this institution together. Hierarchies are deeply embedded in the ethos of the judicial branch and are most noticeable in two particular realms: its organization and the ranks in federal courts.

The Mexican Constitution and other secondary laws that regulate how the judicial branch should be organized have created a downward pyramid in which the Supreme Court rests at the top of a strictly ordered pyramid. These hierarchies stratify salaries, work settings, workloads, and duties, while creating a bureaucratic culture. Therefore, subordination, authority, and social status between junior and senior officials homogenize judicial criteria to decide cases because a complacent attitude grows out of obedience.

One example of this is the fact that there are no guidelines regarding the boundaries of the judge's discretionary power over his or her employees. The only yardstick is how much work the courtroom has, and the vast majority of federal courts have excessive workloads, notably district courts. In consequence, all employees work overtime and on weekends. The courtrooms' official hours are from 9:00 am to 2:30 pm. However, what greatly varies is how employees perform their duties. Some judges demand that employees work until midnight, with little or no time for lunch or dinner. Others allow employees to go home in the early evening and take work home. Some judges and justices do not care about employees' work schedules after official hours, as long as they finish their work. It is up to the judge or justice to organize the work setting, leaving employees powerless to decide how best to do their jobs. Many interviewees complained that this arbitrariness was a major issue in the everyday activities of district courts because it affected both employees and the administration of justice.

This quasi-authoritarian managerial style is a remnant from the old bureaucratic system that governed Mexico for decades. Political clientelism, populism, and loyalty to cliques were the tools the regime used to dominate society and administrative settings. The person in charge of any public office was the 
Esta revista forma parte del acervo de la Biblioteca Jurídica Virtual del Instituto de Investigaciones Jurídicas de la UNAM

boss and subordinates had to obey without complaint if they wanted to keep their jobs. The federal judiciary was not excluded from this influence. Cronyism still plagues this institution, and so do subordination and strict hierarchies. ${ }^{8}$

\section{Too Much Work!}

Another important feature that distinguishes and shapes federal courts is the excessive amount of work. This is by no means exclusive to the Mexican Federal Judiciary. In general, the entire Mexican administration of justice suffers from disproportionate workloads. Unlike other justice-related institutions in Mexico, the MFJ and the district courts in particular have to comply with fixed deadlines set by law to carry out everyday proceedings and trials despite their workload. The administrative branch of the MFJ, the Judicial Council, has created several mechanisms to expedite trial proceedings. Among these mechanisms, there is a program called Sistema Integral de Seguimiento de Expedientes or SISE (Case Monitoring System) to electronically monitor and follow every single step of a trial. There are also statistical summaries and reports that every district court has to submit to the Council monthly to show that the court does not have any backlog. In addition, the Council closely watches and monitors judges and employees to make sure that trial and appeals courts are run efficiently, productively, and according to the law.

Nearly $96 \%$ of interviewees (43) pointed out that the MFJ has too much work all the time, mostly in district courts. Interviewee Felipe said, "Las jornadas de trabajo son muy largas" (The work schedules are very long). Another interviewee, Lourdes, put it this way: "Es demasiado el trabajo que hay que hacer en el colegiado, hay que analizar asuntos voluminosos y hacer trabajo de fondo, estudiar bien para poder hacer un buen proyecto" (There is too much work in the appeals courts. You have to do in-depth analyses of cumbersome cases, examine it well to be able to make a good draft judgment).

Proceeding deadlines pose great challenges for district courts when they have to issue an arrest warrant for organized crime cases because the indictment usually involves multiple defendants and the file is thousands of pages long. Interviewees said that in those types of cases, almost everyone in the court has to stay overnight to work on the file in order to have the warrant ready for the due date. Interviewee Natalia said that, in 2006, her court handled the case of a former Mexican president who was indicted on charges of genocide for the killing of unarmed students in 1968. The indictment contained 80 files of documents, hundreds of pages each, and the warrant of arrest was issued on

8 Beatriz Magaloni, Authoritarianism, Democracy and the Supreme Court: Horizontal Exchange and the Rule of Law in Mexico, in Democratic Accountability in Latin America, 266, 305, (S. Mainwaring \& C. Welna eds., 2003). Carlos Elizondo Mayer-Serra \& Ana Laura Magaloni Kerpel, Form is content: How are justices appointed and how do they decide in the Supreme Court of Fustice, 23 julio-diciembre, Revista Mexicana de Derecho Constitucional (2010). Schatz et al, supra note 5. 
Esta revista forma parte del acervo de la Biblioteca Jurídica Virtual del Instituto de Investigaciones Jurídicas de la UNAM

time. Natalia stated, "Estos trámites de muchos tomos y voluminosos no son tan raros y nos llegan con cierta frecuencia" (These procedures with multiple files and massive ones are not that uncommon and we get them quite often).

There are two other court duties that exacerbate the workload in district courts, and to a lesser extent appeals courts: 1. Court shifts (Turnos) and 2. On duty shifts (Guardias). The first refers to the period that each district court accepts and processes indictments from the prosecutor's office. This period varies from jurisdiction to jurisdiction depending on the number of district courts in each jurisdiction. On-duty shifts refer to employees' availability at all times if there is a legal emergency that requires court intervention. For instance, when an outstanding arrest warrant from a district court has been served late at night and the defendant wants to be bailed out as soon as possible, court employees must be available to process the petition. Both on-duty and court shifts require most employees to stay longer in the district court facilities. This not only imposes a heavier burden of work on them, but it also disrupts their personal life.

\section{High Salaries and Vocation}

According to more than $90 \%$ of interviewees (41), wages are among the best aspects of this institution. Except for the lowest level of the hierarchy, typists, all interviewees agreed that their salaries were remunerative although not everyone conceded that those salaries make up for all the work done in courts and the working conditions. For instance, interviewee Jazmín said, " $E l$ salario sí compensa el trabajo y las responsabilidades de laborar en el tribunal porque es un buen sueldo comparado con otras instituciones o con el poder judicial del fuero común" (The salary does compensate for the work and responsibilities of working at the court because it is a good salary compared to other government institutions or state judicial systems). Interviewee Héctor put it this way: "Los salaries son buenos y existen buenas prestaciones, sin embargo no compensan todo el trabajo que se hace" (The salaries are good and there are good benefits, but they do not compensate for all the work done).

It is worth mentioning that, except for typists, nobody else receives payment for overtime. In fact, the concept of overtime is alien to MFJ employees because they are not hired to work by the hour, but to do specific tasks. These tasks include judgments, conducting court proceedings, process serving, and everything else needed to run the court regardless of the amount of work and how long it takes to accomplish it. Court workers are paid for this entire bundle, so to speak, and working overtime is understood as part of the job. Anyhow, interviewee Natalia suggested that paying overtime could improve the administration of justice.

Interviewees used a particular phrase, salarios buenos (good salaries), to emphasize that the payment for their work was financially rewarding. They 
Esta revista forma parte del acervo de la Biblioteca Jurídica Virtual del Instituto de Investigaciones Jurídicas de la UNAM

acknowledged that salaries were a powerful incentive that attracted many lawyers to work at the MFJ. However, some interviewees thought that salaries were not high enough to make a career out of working at the MFJ. Given the disruptive job schedule and the endless amount of work, something else was needed besides remunerative wages to truly accept these working conditions. Several interviewees suggested having a vocation while others, passion. Others used the words addiction to the proceedings (adicción a los asuntos) and yet others highlighted the intellectual challenges of solving complicated legal matters as a thrill of working there.

Not all MFJ employees were of a mind to enjoy their jobs, according to interviewees. They argued that most employees in the court were proud and happy to work there, but a few coworkers lacked the motivation to perform their duties responsibly. According to these interviewees, unmotivated employees struggled to deal with the stress and busy schedules of the court because they did not like the work environment. Employees without any intellectual motivation worked at the MFJ only because of the good salary, but hated the demands of everyday proceedings. A few interviewees defined these people as chambistas (jobbers) a concept derived from the Mexican word chamba. These employees did not value the privilege of being part of the MFJ or the ethical and social responsibilities that come with it.

\section{Fustices, Appeals Fudges, and Council Member Salaries}

There has been heated debate in Mexico over the past years about the fairness of the salaries earned by high-ranking members of the MFJ. In the mid-2000s, it became public that many Mexican public officials, like mayors and Supreme Court Justices, had a salary higher than the President of the country did. This news caused an outcry and strong criticism from society and political pundits. As a result, the Constitution was amended in 2009 to set up caps on government employee salaries. ${ }^{9}$

The Supreme Court has also come under strong criticism because its operating costs are extremely high and even higher than those for Supreme Courts in other countries. Two Mexican scholars who have studied the Mexican administration of justice, Magaloni Kerpel and Mayer-Sierra, did a comparative analysis of Supreme Courts from different countries. Based on an analysis of information from 2009, they found out that Mexican Supreme Court Justices are among the best paid in the world compared to similar positions. In Mexico, a Supreme Court Justice (Ministro de la Corte) had an average annual salary of $\$ 320,765$ dollars in $2009(4,169,957$ pesos at an exchange rate of 13 pesos per dollar). In Canada, a Justice made an average

9 Sergio Javier Jiménez, Ningún funcionario podrá ganar más que el Presidente, EL UnIVERsal, August 22, 2009, available at http://www.eluniversal.com.mx/nacion/170788.html . 
Esta revista forma parte del acervo de la Biblioteca Jurídica Virtual del Instituto de Investigaciones Jurídicas de la UNAM

of $\$ 296,940$. In the United States, the salary was $\$ 222,301$. In Germany, it was $\$ 197,937$, and in Colombia, $\$ 136,763$. $^{10}$

Based on this institutional context it should not be a surprise that there was a great dissimilarity of opinions on whether or not the current salaries of high-ranking officials at the MFJ were fair and justified. Among those who disagree with the salaries was interviewee Pedro, who said, "El sueldo de los ministros no creo que este justificado porque ganan un cantidad estratosférica y comparado con lo que ganamos el resto del personal es injusto por decir lo menos" (I do not think Justices' salaries are justified because they make a stratospheric amount of money and, compared to what the rest of court employees make, it is unfair to say the least).

Most, but not all, low-ranking officials tended to disapprove of the high salaries of those at the top of the MFJ because they consider them unfair and disproportionate. According to the Supreme Court ${ }^{11}$ in 2011, a court clerka middle-ranking official - made approximately $\$ 47,256$ a year $(\$ 614,340$ pesos) while a typist at the bottom of the hierarchy made approximately $\$ 14,671$ a year $(\$ 190,728$ pesos). The average salary for a low-ranking official would be between $\$ 16,000$ and $\$ 18,000$ a year, generally speaking. To put it into context, in January 2012 the daily minimum salary in Mexico was $\$ 62.33$ pesos for an 8 hour shift, which accounts for $\$ 0.60$ cents per hour of work. This means that even the lowest salaries in the MFJ are considerably higher than the minimum wage.

The topic of salaries - either one's own or somebody else's - was deeply engrained in the ethos of the MFJ because it was associated with different phenomena in the everyday affairs of the institution. For instance, good salaries were seen as the main reason for the lack of petty corruption (called mordidas in Spanish). Employees who wanted to change jobs due to the high levels of stress in district courts were normally dissuaded from doing so because no other government institution would match their salaries. Most MFJ employees work hard because they know that their salaries are among the best in the field, and given the strong competition for positions, they fulfill their work duties responsibly to keep their jobs. In addition, good salaries attract many young and brilliant lawyers to work at the federal court, which helps the institution to recruit the best applicants.

\section{Handling MiscondudcT}

\section{The Ambiguity of Corruption}

The topic of corruption was a crucial part of the research project in order to learn what interviewees had to say about it. Most of them understood cor-

\footnotetext{
10 Mayer-Serra, supra note 8.

11 Diario Oficial de la Federación [D.O.] [Federal Official Publication], (Mex.).
} 
ruption as a dishonest act done to obtain benefits - usually money - through unacceptable methods, such as bribery or extortion. However, nepotism, the use of connections, and cronyism were not precisely defined as corrupt behaviors, but as inconvenient traditional practices that were part of the institution and did not necessarily influence the judicial process. Not everyone adhered to this perspective though and several respondents condemned the latter phenomena, labelling them negatively by using categories ranging from inappropriate behavior and misconduct to gross corruption. Their responses extended from severe disapproval of the problem to resignation to the current status quo, as if simply accepting that nothing could be done to change the culture.

The concept of corruption among MFJ court staff and senior officials was not the same for everyone. . For some but not all senior officials, accepting any amount of money regardless of the circumstances was a corrupt act. Other high-ranking officials had a more flexible view and did not always condemn receiving money from the public if the money was intended to be a tip. According to them, a tip was a pecuniary expression of gratitude for a job done and occurred more frequently among low-ranking employees. Because practices such as cronyism, connections, and nepotism did not fit this profile, not everyone defined them as corruption per se. Some interviewees - typically the younger generations of judges - did condemn nepotism and cronyism as blatant acts of corruption because they had the potential to affect the outcome of a trial.

According to Transparency International (a non-governmental organization that monitors corruption worldwide), judicial corruption is defined as "any inappropriate influence on the impartiality of the judicial process by any actor within the court system.." 12 If this definition were used as the yardstick to measure corruption in the MFJ, then this problem would have a narrower and more specific perception of which broad range of practices would be labeled as corruption. It would not be so difficult to figure out that the use of connections, nepotism, and cronyism could influence a verdict, and should undoubtedly be defined as corrupt acts. Yet that was not the case in the MFJ.

The vast majority of interviewees - including high-ranking officials - acknowledged that corruption exists in the MFJ. The only discrepancy among them was the amount of prevalent corruption: interviewees' estimates ranged from $1 \%$ to a maximum of $10 \%$. Since more than half of the respondents' perception was between these two numbers, it is possible to deduce that the prevalence of corruption varies from $5 \%$ to $10 \%$ depending on the jurisdiction and the type of court. Corruption in this context is based on the definition provided by Transparency International - any inappropriate influence in the impartiality of a trial within a court by anyone. This definition of

12 Transparency International, Global Corruption Report 2007 xxi, (Cambridge University Press, 2007). 
Esta revista forma parte del acervo de la Biblioteca Jurídica Virtual del Instituto de Investigaciones Jurídicas de la UNAM

corruption includes the use of connections, cronyism, and nepotism when employed to affect the outcome of judicial proceedings.

\section{Traffic of Influence and the Use of Connections}

The phenomena of traffic of influence (which can be translated as a combination of influence peddling and nepotism), connections, and favoritism among public servants have been deeply embedded in Mexican society for many decades. ${ }^{13}$ The authoritarian regime of the last century based its political recruitment on a system of rewards, loyalty, and obedience to the boss. This system permeated the entire government administration and became part of the ethos of Mexican bureaucracy.

The ancien régime lost its power in 2000, and now a democratic transition is underway. However, the inertia of the past still maintains many of the old undemocratic practices that provided political stability in the past century. Among those practices are the traffic of influence and the use of connections. Even for those government institutions that have become more independent and democratic, such as the federal judiciary, it has been a challenge to eradicate these phenomena.

Eighty percent of interviewees (36) said that favoritism and connections indeed exist, while $20 \%$ of respondents (9) said they do not. Among those who denied the existence of these phenomena was interviewee Diego, who said, "Anteriormente quizá si eran valiosas las palancas y los amigos, pero se ha transparentado la institución y ya no es necesario" (Maybe before, contacts and friends were invaluable, but the institution has become more transparent and they are no longer necessary). Interviewee Wilfrido was among those who categorically admitted the existence of these phenomena as part of the everyday affairs at the MFJ. He said, "Si ayudaría [tener amigos o contactos] porque esa es la actitud, es sólo un reflejo de la sociedad mexicana, como en todo. Siempre que hay exámenes pasan los que tienen palancas, claro también los otros, pero los recomendados siempre" (Yes, it would help [to have friends or connections] because that is the only game in town. It is just a reflection of Mexican society, as in everything. Whenever there is a selection process [for court appointments], only those who have contacts pass. Of course, others do too, but those with connections always do).

\section{Caveats on the Use of Connections}

Among those who responded yes to the problem of the use of connections most did so with a caveat. They said that the use of connections and traffic of influence was not a systemic or consistent practice. It varied extensively

13 Peter H. Smith, Labyrinths of Power: Political Recruitment in the Twentieth Century Mexico (Princeton University Press, 1979). 
depending on the person who did it, as well as on his or her hierarchy in the institution, interests at stake, and the implications of engaging in such practices. Sometimes some people would use these practices under specific circumstances, and other times the same people would not use them even if they had the power to do so. There was no specific pattern of how or when the connections would be used. For instance, some interviewees knew cases in which junior employees have made it to the top of the hierarchy based on personal credentials. However, they also knew that a few individuals, usually relatives of high-ranking members, did not have the proper credentials and yet they made it to the top. However, these cases were more the exception than the rule.

One interviewee, Andrés, highlighted something important: favoring someone is more a combination of different circumstances than merely the use of connections and traffic of influence per se. He explained that the head of the MFJ has a double standard for appointing senior officials. On the one hand, the MFJ has set up a strict selection system to recruit the best candidates based on merit, such as written and oral exams, experience, education, and seniority. This process allows only the best of the best lawyers to advance to become judges and justices in federal courts. On the other hand, it has created exceptions to that system by which people without the right qualifications have also gotten ahead through a subtle mechanism based on connections.

A common example of this aforementioned mechanism - described by several interviewees - is when the Judicial Council makes "special" vacancy call for new judges and justices (convocatorias para ser juez o magistrado). These vacancies are specifically designed for employees working in any of the highranking offices, such as the Supreme Court, the Judicial Council, and the Federal Electoral Court. These vacancies exclude anyone else in the MFJ from applying, and the requirements are usually less demanding than general vacancy calls. This policy has conveniently left the door open to allow relatives, friends, and members of one's clique to fill senior positions. Several interviewees from senior and junior positions confirmed this procedure for appointing judges and justices using two different criteria. These interviewees used a particular concept-verb to describe this phenomenon: campechanear. Campechanear in Mexican Spanish means to mix different things, mostly in cooking. It comes from the word campechana, which is a seafood cocktail. In the context of the MFJ, interviewees defined campechanear as the Council's approach to select judges and justices using two different methods: 1. credentials and 2. connections, traffic of influence, or nepotism.

Even though the use of connections and traffic of influence is prohibited by law, many officials carry out such practices discreetly and without leaving traces. As professionals of the law, they know how to circumvent restrictions by finding loopholes. Since justices and council members are all at the top, 
they know that their actions cannot be scrutinized by a higher authority, not to mention the inertia of secrecy that permeates parts of the MFJ.

That being said, the fact is that the use of connections and traffic of influence in the federal judicial system has gradually declined over the past decade in comparison with how widespread it was during the authoritarian regime a few decades ago. Several interviewees coincided in their responses saying that the MFJ changed after the 1994-1995 reform and became a more professionalized and respectable institution. Among those changes was the founding of a real system of meritocracy where employees with no connections can make it to the top. These responses coincide with analyses from scholars who have studied the federal judiciary and the 1994-1995 judicial reform. ${ }^{14}$

In addition, the use of connections and traffic of influence has been limited in general to administrative affairs, such as appointments of typists or personal assistants. Although there is no evidence that these phenomena pose a serious problem to trials or the administration of justice as a whole, there have been some exceptions to this generalization according to some interviewees.

Finally, there is evidence that not all senior officials use connections or traffic of influence to favor employees, friends, or relatives. At least $50 \%$ of high-ranking officials (5) in this sample said during the interview that these phenomena were ethically wrong and damaging to the institution. Therefore, they refused to engage in these practices and have tried to eliminate them. Notwithstanding, these phenomena are still part of the federal judiciary as most interviewees acknowledged. Interestingly, there is a similar problem that is particularly rampant in the MFJ: nepotism. The vast majority of interviewees said that it has been difficult to cope with nepotism because almost everyone benefits from it.

\section{The Normalization of Nepotism}

In the MFJ, connections and traffic of influence are used to favor friends and members of one's clique to obtain positions and climb the echelons of the institution. Nepotism, on the other hand, is used first to favor one's relatives in obtaining jobs, and then to help them climb the hierarchical ladder. The difference between nepotism and traffic of influence is that the latter refers to favoritism and/or preferential treatment in government affairs to ben-

14 Pilar Domingo, Judicial Independence: The Politics of the Supreme Court in Mexico, Vol. 32 No. 3, Fournal of Latin American Studies 705, 737 (2000). Héctor Fix-Fierro, Judicial Reform and the Supreme Court of Mexico: The trajectory of three years, Vol. 6 No. 1, United States-Mexico Law fournal 1,21 (1998). Schatz, supra note 6. Jeffrey K. Staton, Lobbying for Judicial Reform: The Role of the Mexican Supreme Court in Institutional Selection, in Reforming the Administration of Justice in Mexico 272, 296 (W.A. Cornelius \& D. Shirk eds., 2007). 
efit friends or one's clique while the former is favoritism shown by someone in power to relatives, usually by appointing them to jobs. These jobs do not have to be high ranking positions as long as they represent steady employment.

Nearly $80 \%$ of the respondents (35) admitted that nepotism exists as part of everyday life at the MFJ. It has become a naturalized practice because everyone - among senior officials - does it and benefits from it. Even junior employees, if they can, would use their connections to find a job for a relative because they know that MFJ salaries are better than those in other institutions. To get a job in this institution a person does not have to be a lawyer because there are dozens of administrative positions that do not require a law degree.

In Mexico, and certainly inside the federal judiciary, nepotism does not have the negative connotation that it might have elsewhere. This has to do with the sociocultural understanding of the Mexican family. Riding ${ }^{15}$ argues that the family has been a powerful and conservative institution that has given political stability to Mexico. He asserts: "Those with jobs look to place unemployed relatives: in homes with extensive domestic service, the maid, chauffer and gardener may belong to the same family... Within the government, nepotism at the highest levels may be frowned upon, yet entire families will be brought into the bureaucracy by some relative with influence." 16 As the quote suggests, helping a relative get a job is not just socially acceptable but doing otherwise would be reprehensible in everyone's eyes.

Family is considered more important and respectable than one's job or any government office because it offers a support structure that no one else can provide. Family is also a reliable and a trusted domain, one that is probably more important than respecting the law or any personal interest. Although the concept of family has changed and become less traditional in the new millennium, some of those old features still prevail in Mexican society. Authors like Lomnitz, ${ }^{17}$ Morris, ${ }^{18}$ and Smith, ${ }^{19}$ support the argument that family ties and socialization play a crucial role in reproducing phenomena such as nepotism and corruption.

Based on this contextualization of the Mexican family, it is not difficult to understand why nepotism is perceived as acceptable in the MFJ. As with other practices in Mexican society involving wrongdoing, people use euphemisms to refer to nepotism. ${ }^{20}$ Senior and junior officials would never refer to

15 Alan Riding, Vecinos Distantes: Un Retrato de los Mexicanos (Joaquín Mortiz, 1985).

16 Id

17 Claudio Lomnitz (ed.), Vicios Públicos, Virtudes Privadas: La Corrupción en México (Porrúa, 2000),

18 Stephen D. Morris, Corruption and Politics in Contemporary Mexico (University of Alabama Press, 1991).

19 Smith, supra note 13.

20 Gabriel Ferreyra-Orozco, Understanding corruption in a state supreme court in Central Mexico: an ethnographic approach, Vol. 69, No. 3, Human Organization 242, 251 (2010). 
Esta revista forma parte del acervo de la Biblioteca Jurídica Virtual del Instituto de Investigaciones Jurídicas de la UNAM

nepotism using that word but instead terms such as favores (favors), dar chamba (give a job), and favores de chamba (employment favors). By using euphemisms, MFJ employees take away their disapproval of the word nepotism and no longer see it as harmful and objectionable.

Most of the interviewees $(80 \%)$ who talked about nepotism used the phrase favores de chamba to describe this phenomenon, but others used different words, such as mafias, malas prácticas (bad practices), and recomendados (recommended people). Interviewee Elizabeth said, "Muchos jueces de distrito que acaban de ser nombrados son hijos o sobrinos de magistrados o ministros. Aparentemente los exámenes de selección son la regla pero todo es una mafia desde arriba" (Many newly appointed district court judges are children, nieces or nephews of appeals judges or justices. It seems that entrance exams are the rule, but it is a complete mafia coming from the top).

Nearly $20 \%$ of interviewees (10) said that the Judicial Council is well aware of the epidemic proportions of nepotism and has tried to stop or at least reduce it. The usual approach has been to change a bylaw to penalize its practice but none of those measures has succeeded for two major reasons: One is that most of the attempts to eliminate nepotism have not truly intended to fix the problem given that the Council and its members benefit from nepotism. Secondly, modifying the law to impose harder sanctions against those who engage in nepotism is condemned to fail because senior officials are lawyers who know the law better than anyone else and thus they can always find loopholes to circumvent it.

Meritocracy in the MFJ is more than just a reward system based on personal credentials. It also involves developing social networks to find opportunities. It is within this network of friends, acquaintances, former bosses, peers, and coworkers that favores de chamba are requested and given. Those who benefit from favoritism, either through connections, traffic of influence, or nepotism, are nicknamed recomendados, a derivative term from the verb recomendar, which means to recommend. At least $10 \%$ of the interviewees (5) mentioned that having recomendados in one's district court is a doubled-edged sword because they can be responsible workers and fulfill the demands of the job or they can be exactly the opposite. In either case, the head of the court has to tolerate the person because there is an unwritten rule among senior officials that, regardless of the performance of recomendados, their employment is always guaranteed. This may sound silly if the recomendado turns out to be a failure, but it is a procedure to assure them permanent employment status. According to interviewees, some, but not all, recomendados enjoy quite a few benefits that other employees do not, such as shorter work schedules, more time off, and less demanding work. In any case, the recomendado's assessment and working conditions would depend on who the recomendado is, who recommended him or her, the recomendado's position, and whether he or she is pursuing a career in the MFJ. 
From the analysis of the interviewees' narratives, it can be inferred that nepotism is not a black-and-white phenomenon and is not necessarily always negative. For instance, job rotation is a common practice among brand new judges and justices because they are frequently assigned to different jurisdictions early in their careers before they settle into one. Favores de chamba is a pragmatic practice to provide employment for spouses if needed. Family members of judges and magistrates sometimes reach high-ranking positions not because of nepotism, but because they are smart and have to prove it by excelling at their jobs. Among the negative implications of nepotism and recomendados are an unfair system of appointments, abuse of power by senior officials, and an inconsistent meritocratic process.

Nepotism is not an isolated phenomenon, but one intertwined with other institutional practices, such as strong hierarchies, heavy centralism, and a male-centered culture, that have characterized the federal judiciary. Regardless of the outcomes, nepotism is a self-defeating practice in the administration of justice because it creates a second-class category for those employees who do not have relatives in powerful positions. It also contradicts the principles of fairness and equality that should be at the core of a federal judicial system. Nonetheless, it is essential to take into account the social context in which the phenomenon takes place in order to understand it more accurately and address it accordingly.

\section{Handling Drug-Related Trials: Are Cartels at Threat to the MFJ?}

During interviews, many interviewees said that drug cartels were a threat to the MFJ, but not everyone agreed with this perspective. Those who felt intimidated by potential harm from cartels cited cases where MFJ officials have been threatened or targeted by these criminal organizations. These interviewees usually knew of threats against peers or court employees in their jurisdictions or somewhere else, although they did not specify whether these threats came from drug cartels or someone else.

Some respondents said that threats from drug cartels against court employees were not common because drug traffickers, or their attorneys, for that matter, knew that staff and junior officials could not decide a trial. Only a judge had the power to free or jail a defendant in a sentence and most judges would not dare to acquit a criminal without evidence to support that decision. The corollary was that high salaries, social status, and the overall job benefits of working at the MFJ discouraged most senior officials from engaging in corrupt acts.

An interesting argument to explain the unlikelihood of a judge or junior official accepting bribes from drug cartels is that once someone does it, she or he has to keep working for the cartels forever. Judges are not stupid, and it would be improbable that any high-ranking official would agree to be bribed 
by drug traffickers' lawyers. Yet, there are exceptional cases in which judges and/or justices might accept bribes from attorneys representing drug cartels members. Because this statement would be difficult to prove, there is no direct evidence of these cases. However, the Michoacanazo trial offers an example of a case in which a drug cartel or local officials probably influenced the judicial process by bribing a federal judge. ${ }^{21}$

Overall, many interviewees implied that threats against court staff and senior officials have increased in the last decade. The number and type of threats vary from jurisdiction to jurisdiction. Some threats came via phone calls to secretaries, and others were made to process servers face-to-face by angry defendants serving time in prison. In Tijuana, a junior official received a corona de muertos (a funeral wreath) at her office as a threat, implying that she would be dead soon. Two interviewees recounted the cases of two judges who had to flee the states of Chihuahua and Baja California after receiving death threats regarding the verdicts of trials under their jurisdiction. There is not enough information from the collected data to determine the percentage of these threats that comes from drug-related cases, but it is logical to conclude that not all of the threats were made by drug cartels. Sometimes angry parties who blame the judge or the judicial system for a verdict against them can also send threats.

Regardless of the origins of threats, the MFJ has developed mechanisms to cope with them to guarantee senior officials protection against potential harm. Among other things, the MFJ now provides armored vehicles for judges in district courts who handle high-profile drug trafficking cases or for some who work in jurisdictions along the Mexico-U.S. border. The Judicial Council, in coordination with the Attorney General's Office, supplies bodyguards for senior officials who have received credible threats. The effectiveness of bodyguards was proven in 2010 when a federal judge in the state of Nayarit who was handling high profile drug trafficking cases was attacked and his bodyguards saved his life, although one of them was killed. ${ }^{22}$ Job rotation of senior officials in jurisdictions with high levels of organized crime has been another way to defuse threats and avoid potential cronyism between judges and the law firms that represent drug cartel members.

To protect the federal court premises, the MFJ has hired private security officers to guard all buildings belonging to the institution. The Council has invested in metal detectors and x-ray machines to scan suitcases, backpacks, and any bags that come into the federal courts. All employees and visitors have to wear badges while doing business in the courts. Visitors and litigants also have to sign in and show a picture ID to have access to the premises. In

21 Gabriel Ferreyra, The Michoacanazo: A case-study of wrongdoing in the Mexican Federal Judiciary, Vol VIII No.1, Mexican Law Review 3, 31 (2015).

22 Atacan al juez Elorza Amores; matan a un escolta y hieren a 2. LA JORNADA, August 20, 2010, available at http://wrere.jornada.unam.mx/2010/08/20/politica/011n1pol. 
addition, people who want to talk to a judge need to make an appointment with a secretary (as a type of screening process) and justify their legal interest in speaking to the judge (unlike the U.S., in Mexico it is legal for trial parties to meet with the judge separately). Although a decade ago few of these measures - such as wearing badges to access courts - were irregularly implemented, they have now become part of the official policy in all MFJ jurisdictions and are strongly enforced.

These changes have had a positive impact among citizens and the community of attorneys that litigate in federal courts because it shows that the institution can be professional and well organized. In this regard, the federal judiciary distances itself from the state judicial systems, which tend to be less organized in terms of protecting their employees and premises - with a few exceptions - probably due to lack of money and institutional support from state governments.

\section{When the Rule of Law Leads to Impunity}

The MFJ has been praised for its unconditional respect for the rule of law. The institution itself is proud of this principle, and has an official policy to protect individual rights based on strict obedience to the law even if this generates impunity. For the MFJ, legality trumps the punishment of criminals and justice for victims. The most striking example of this attitude - and, unfortunately, the most common one - is when criminals walk free from prison due to legal technicalities or mistakes made in the public prosecutor's office. A judge in a district court spoke of a case under his jurisdiction to explain this official policy for applying the rule of law unconditionally:

Un caso que me pasó recién llegué a este juzgado es que había un juicio donde dos personas habian sido detenidas por delitos graves, y aunque si eran responsables del delito, por la forma en que se llevaron a cabo esas detenciones fueron arbitrarias y violando gravemente las garantías de los detenidos de modo que resolvi dejarlos en libertad. (One case I had when I first came to this court was a trial in which two people had been arrested for felony charges. Although they were responsible for the crimes, I had to rule to release them because the arrests were carried out arbitrarily and in serious violation of the detainees' civil rights.)

This description is the archetypical representation of the most familiar face of impunity and injustice in the Mexican federal judicial system. The MFJ is not the only one to blame for these maladies. Other government agencies in the criminal justice system also play a role in this process, and errors such as deficient criminal inquiries, inadequate police investigations, faulty work done by the prosecutor's office, and a literal interpretation of the law contribute to the problem. Then, when a federal judge looks at the indict- 
ment as a whole and the case appears to be deficient and inconclusive, the judge frees the perpetrator more often than not. It would be unfair to only blame the MFJ for releasing criminals on grounds of due process violations because the work of the public prosecutor's office is crucial to producing a credible conviction. Many times, the public prosecutor's office fails to provide convincing evidence that would withstand scrutiny in a court of law. In fact, faulty indictments are the main reason why judges release criminals based on technicalities. However, the MFJ has also contributed to the problem by reproducing judicial criteria and case law that reinforce legalism and blind adherence to the law.

Interviewee Quirina, an expert in the federal judiciary, was extremely critical of this common practice in the MFJ. She said that legitimacy in a trial should be justified by rational verdicts that bring justice to those who resort to the judicial system. Instead, she said, the MFJ has taken a path that solves disputes by strictly applying the law without really providing justice. She pointed out,

Los operadores de la ley - jueces, magistrados, ministros, personal de los tribunales - todavía funcionan con una mentalidad autoritaria porque los criterios judiciales con que justifican sus resoluciones y trabajo son rigoristas, legalistas, y olvidan la esencia de un juicio. (Legal operators - judges, appeals judges, justices, and court staff-still work with an authoritarian mentality because the judicial criteria underlying their verdicts and work are rigorous, legalistic, and they forget the essence of a trial).

To put her criticism into context, Quirina said that after the 1994-1995 judicial reform that resulted in the establishment of the Judicial Council, all its "new" members belonged to the MFJ's rank and file- justices and counselors were appointed from a pool of federal judges and justices - who already had a preconceived notion of what judgeship meant. According to her, their judicial criteria and sentencing guidelines reproduced the authoritarian thinking and patterns that had prevailed at the MFJ during the tenure of the ancient regime. By not introducing a new generation of legal experts, who would have probably been exposed to different legal paradigms and interpretations of the law, the MFJ only changed its façade, but the mental framework remained the same.

In many ways, the MFJ keeps repeating old practices (e.g. nepotism, rigid judicial criteria, cronyism, and bureaucracy) which does not reflect well upon a branch of government that should uphold exemplary behavior in a transitional democracy. As long as the MFJ refuses to acknowledge the need for an overhaul of its bylaws and sentencing criteria, Mexican society will continue blaming this institution for the impunity and the lack of justice in Mexico. 
Esta revista forma parte del acervo de la Biblioteca Jurídica Virtual del Instituto de Investigaciones Jurídicas de la UNAM

\section{Gulture, Inequality, And Discrimination}

\section{Structural and Institutional Inequalities at the MFJ}

Another subtle but common problem in the MFJ, rooted in patriarchalism and authoritarianism from the past, is structural and institutional inequality. This inequality, or rather inequalities, had not been acknowledged until recently, and then, just superficially. Inequalities at the MFJ are subtle and well established in both the institutional and cultural realms. Culturally speaking, MFJ ethos reflects the traditional values of Mexican society: patriarchalism, centralism, hierarchical divisions, formalism, bureaucratic organization, and a strong resistance to innovation. These features are represented in a myriad of ways, such as wage disparities, labor divisions, office space, social status, and above all gender discrimination.

First, there is a huge income gap between justices and council members and low-ranking officials despite the fact that most of the intellectual and physical work is done by the latter. Gender discrimination has led to inequalities in which many women have been confined to clerical work while men hold most of the powerful decision-making positions. According to the Judicial Council, more than 50\% of the employees in the MFJ are women, but they only account for $20 \%$ of judges and justices . At the top of the institution, this disparity is even worse: out of eleven justices only two are women, and only until recently two women have joined the seven members of the Judicial Council.

Deep patriarchalism and strong Catholicism are two factors that have been woven together for centuries to keep Mexican women in traditional roles, such as housewives and mothers, or to restrict them to doing jobs considered feminine. This is not the case anymore in the overall conditions of Mexican society where women have been able to narrow the gender gap and make strides in urban settings over the past two decades. Nevertheless, broad gender inequalities still exist.

What came as a surprise during the fieldwork were the arguments interviewees used to justify gender inequalities. Except for one female, all interviewees agreed that the MFJ did not discriminate against women. The reality was - according to these respondents - that women did not want to become judges or justices because it conflicted with their roles as mothers and wives. They cited the long working hours, frequent job rotation in multiple jurisdictions, and sketchy schedules - including working on weekends - to support their claim.

Magdalena, a female judge with 32 years of experience in the MFJ, said: "No es discriminación sino una decision personal de las mujeres de no participar porque ello implica muchos otros compromisos de cambiarse de adscripción y si se tienen hijos o están casadas lo piensan mucho" (It is not discrimination [against women] but a woman's personal decision not to participate [in the selection process to 
Esta revista forma parte del acervo de la Biblioteca Jurídica Virtual del Instituto de Investigaciones Jurídicas de la UNAM

become judge] because it implies many other commitments in moving to another jurisdiction, and they [women] think twice about doing this if they have children or are married). Another interviewee, Sara, a brand new judge, said,

Muchas mujeres privilegian la vida personal por encima de cuestiones laborales y se resisten a ser titulares porque saben que van a tener cambios de adscripción, lo cual implica moverse con toda la familia y es dificil que el esposo siga a la esposa. (Many women choose personal life over a professional career, and they decide not to become judges because they know they will have to change jurisdictions, which implies moving their entire family and it is not very likely that the husband will follow his wife.)

These two respondents show how most of the interviewees explain the gender gap among judges and justices. Although these arguments are true in the sense that gender inequalities in Mexico have long been present and are visible in many institutions, the MFJ has failed, first, to acknowledge this unequal treatment of women, and second, to implement changes to reduce gender disparity.

\section{Traditional Gender Roles and Stereotypes}

Only recently has the MFJ begun to take steps towards addressing this problem. For instance, aware that gender discrimination might exist, the Supreme Court created a new office called Coordinación General del Programa de Equidad de Género del Poder Fudicial Federal (General Coordinating Office of the Mexican Federal Judiciary Gender Equality Program) in 2008. This office and its program aim to create awareness about gender equality among judges and personnel. The goal was for employees to become familiar with gender equality in their sentencing guidelines and to create a work environment free of gender discrimination and violence. This office was eventually replaced by the Interinstitutional Committee of Gender Equality of the Mexican Federal Judiciary in May 2010. ${ }^{23}$

The former Office of Gender Equality conducted ethnographic research within the Supreme Court in 2008-2009 to find out whether there was any discrimination against women and how pervasive the problem was. It also carried out a national survey among MFJ employees from all jurisdictions. ${ }^{24}$ The findings from these two studies confirmed that institutional discrimination against women exists throughout the MFJ. The glass ceiling is one mechanism that perpetuates the problem.

23 Suprema Corte de Justicia de la Nación [Mexican Supreme Court], Webpage (2017), available at http://portales.te.gob.mx/genero_imparticion_justicia/view/inside/antecedentes.

24 Suprema Corte de Justicia de la Nación [Mexican Supreme Court]. Resultados de los Diagnósticos Realizados en la Suprema Corte de Justicia de la Nación y el Consejo de la Judicatura en Materia de Equidad de Género 2008-2009 (2011). 
The creation of an office for gender equality means nothing if no specific actions are taken towards changing the status quo. Although it is understandable that any policy intended to reverse long-term patterns of unfair treatment against women would take years to effect institutional change, there is evidence that gender inequality is not a priority for the head of the MFJ. Several trends reinforce this conclusion. For instance, a woman has never been a Chief Justice. Neither the Supreme Court nor the Council has ever considered installing a gender quota so that more women could have access to highranking positions. If the intention to reverse gender discrimination really existed, the Council would set up a recruitment process for female employees to help fill the judge and justice positions. However, this process would be considered discriminatory against men because there is a misunderstanding of what gender equality means in the workplace. Many employees, some women included, think that gender equality means to treat men and women equally without any consideration of the social roles mothers and wives play in the conservative Mexican society. This hegemonic male worldview has been institutionalized and, because the leadership of the MFJ is overwhelmingly made up of men, it seems unfeasible that there will be a change of the status quo in either the short or the medium term.

According to Judicial Council, there are almost 30,000 employees working in the federal judiciary. More than half of these workers are women, but they are greatly underrepresented in high-ranking positions. Only $20 \%$ of judges and justices are women. There were 733 circuit appeal judges -600 men and 133 women - and 356 federal judges - 269 men and 87 women - according to the 2011 Jurisdictional Atlas. ${ }^{25},{ }^{26}$ This gender inequality does not appear to be a concern for the judicial branch despite the existence of an office that is responsible for addressing gender issues within the institution. The Judicial Council has normalized this gender gap by ignoring the topic and addressing only women's issues related to legal matters. In other words, the Council and the entire federal judiciary may acknowledge the fact that Mexican women suffer from discrimination in society, but are incapable of admitting that women working in the judicial branch suffer institutional discrimination within the MFJ. ${ }^{27}$

\section{Conclusions}

This article sheds light on the ordinary activities of the federal judiciary that are little known by most people outside the institution. Knowing these

25 Consejo de la Judicatura Federal, Poder Judicial de la Federación, Atlas JURISDICGIONAL (2011).

26 The latest edition of the Atlas Jurisdiccional in 2014 did not include any demographics, only data about new courtrooms nationwide and jurisdictions.

27 Consejo de la Judicatura Federal, Poder Judicial de la Federación (2011), available at http://werere.cj.gob.mx/ http://werwe.cj.gob.mx/. 
activities offers a different perception of the MFJ and the complexity of the administration of federal justice. These data show that the negative image that the judicial branch has had in the past overshadows its positive features. What is more important is that this document provides a better understanding of the setting and context of the MFJ, which serves as background to comprehend more complex phenomena such as nepotism, abuse of power, misconduct, and corruption.

The Mexican Federal Judiciary is an institution that reproduces the traditional patterns of bureaucracy that have characterized Mexican societyhierarchies, complex regulations, and a strong administrative system. It also portrays a culture of intense work in which excruciating work schedules, effort-intensive jobs, and stressful environments are characteristic of everyday life in the MFJ. Despite these difficult work conditions, most employees and judges accept them as natural features of federal courts. Nearly two-thirds of the interviewees (33) suggested that the unifying factor that holds this setting together is the high salaries and a passion for working in these courts. Practices such as nepotism have become normalized in some sectors of this institution - usually among high-ranking officials - and have therefore lost their negative connotations. Nepotism in particular is widespread, and nearly $80 \%$ of the interviewees (35) acknowledged its existence. Because it is not seen as an immoral or unethical phenomenon, the head of the MFJ has little or no interest to tackle the problem.

Whether it is high-ranking officials' use of connections, nepotism, or influence peddling, these practices still exist because of the culture of strict obedience, loyalty, and powerful hierarchies derived from the inertia of the ancient régime. According to respondents who acknowledged misconduct, these practices are not as prevalent as in the past, and have been considerably abated. Except for nepotism, misconduct such as influence peddling and corruption occur only exceptionally and are not a huge problem within the MFJ. Interestingly, there is a doublespeak discourse from some senior officials regarding these phenomena: on the one hand, they officially condemn these practices because they that affect the MFJ, but on the other hand, they reproduce them and benefit from them.

Finally, corruption is a phenomenon that remains part of the MFJ in the broader context of Mexican society and as a legacy from the authoritarian regime. More than $80 \%$ of respondents (37) admitted that corruption takes place at the federal judiciary, but all of them emphasized that it happened only exceptionally. Even those who mentioned a percentage of corruption, such $1 \%, 5 \%$, or $10 \%$, added that it was a rare practice within the larger context of the institution. It is important to understand this emphasis on corruption as an exception because it hints at the institutional mindset of the problem: Yes - employees would admit - there is still corruption in the federal judiciary, but it is not as widespread as it used to be and compared to the rest of the federal bureaucracy, the MFJ is doing a better job on this issue. 
It is a fact that there is corruption in the MFJ - exceptionally but it does occur. Corruption related to drug trafficking and cartels is even rarer than any other kind of corruption because the implications of getting involved with drug cartels are too dangerous, interviewees suggested. None of the respondents mentioned a single case of corruption related to drug trafficking trials. Instead, they said the opposite was true because hardly any judges or justices would do business with cartel members given how organized crime conducts their business. This does not mean that this type of corruption does not take place; it does, but in more subtle ways and it requires more complex mechanisms and behaviors as in the Michoacanazo case. ${ }^{28}$

There are still many challenges ahead for the MFJ before it can become a fully independent and reliable branch of government in the context of the $21^{\text {st }}$ century. Yes, the institution is more independent than before, but legal and political contingencies still make it susceptible to influences from the two other branches of government. A particular phenomenon that deserves special attention is the responsibility of the federal judiciary in the problem of impunity in Mexican society. The MFJ is still caught in old schemes of legalism that perpetuate this problem in the name of adherence to the rule of law. For most federal judges - in trial and appeals courts - the rule of law is considered a sacred paradigm by which verdicts must adhere to a literal interpretation of the law. This strict judicial criterion has allowed many criminals to walk free, and senior officials justify their decisions on legalistic grounds. With the recent overhaul of the Mexican judicial system that switched from an inquisitorial to an adversarial system this problem of impunity could increase. The MFJ should be more flexible in their interpretation of the law in order to keep up with the dynamics of social reality. Because of this shortcoming, there is a disparity between what the law holds as legal and the real world of everyday life, and many times the work of the federal judiciary is unable to make a connection between these two realms and dispense justice to citizens.

These are the major issues that the Mexican federal judiciary must face in the coming years in order to leave behind the negative practices that still prevail within. It is impossible to predict how long it will take for this branch of government to transform into the institution that Mexican society demands. Regardless of this uncertainty, it appears that only when a new generation of judges (younger, more educated, progressive, and gender equal that includes males and females) have filled in enough positions as justices and council members at the top of the MFJ to exert a majority in the Supreme Court and the Judicial Council will this institution be able to leave behind the conservative and rigid thinking inherited from the past century. Then there will come a time when corruption, misconduct, and wrongdoing will be rare occurrences because the principles governing this branch will be professionalism, honesty, compassion, ethics, and respect. Hopefully, this will be the case in the near future.

28 Ferreyra, supra note 21. 